\title{
Gamma heavy chain disease simulating alpha chain disease
}

\author{
S. W. BENDER, F. DANON, J. L. PREUD'HOMME, H. G. POSSELT, \\ P. ROETTGER, AND M. SELIGMANN
}

From the Centres for Paediatrics and Pathology, University Hospital, J. W. Goethe University, Frankfurt/M., Federal Republic of Germany, and Laboratory of Immunochemistry and Immunopathology (INSERM U. 108), Research Institute on Blood Diseases, Hôpital Saint-Louis, Paris, France

SUMmARY A young Turkish girl presented with all the clinicopathological features of a digestive form of alpha chain disease. A gamma heavy chain disease protein, however, was found in her serum and also in the cells invading the intestinal mucosa and mesenteric lymph nodes.

Heavy chain diseases (HCD) are proliferating disorders of $\mathbf{B}$ cells secreting a protein made of a fragment of heavy chain devoid of light chains. Since the initial description of $\gamma$ HCD (Franklin et al., 1964), similar conditions have been recognised for the two other immunoglobulin (Ig) classes, $\alpha$ (Seligmann et al., 1968) and $\mu$ (Forte et al., 1970). Whereas $\gamma$ HCD is usually characterised by a lymphoma affecting lymph nodes, spleen, and bone marrow, $\alpha$ HCD is a disease of the IgA secretory system and involves the small intestine and mesenteric lymph nodes in most cases or the respiratory tract in a few (Seligmann, 1977). This clinical delineation is not as clear cut as was previously thought, as we report here a case where the epidemiological and clinicopathological features were those of $\alpha \mathrm{HCD}$ but where the abnormal protein belonged to the $\gamma$ class.

\section{Case report and methods}

The patient was a 12.5 years old Turkish girl who presented with a three year history of diarrhoea and severe malabsorption with marked physical retardation (height and weight below the third percentile, bone age retarded three years). Physical examination showed finger and toe clubbing and a distended abdomen with palpable tumours. Radiological investigations of the intestine disclosed diffuse involvement of the whole small intestine with considerable thickening of irregular folds in dilated loops (Fig. 1). Laboratory investigations

Address for reprint requests: Dr S. W. Bender, Zentrum des Kinderheilkunde, Klinikum der J. W. Goethe-Universität, Theodor-Stern-Kai 7, D-6000 Frankfurt/M., 70, FRG.

Received for publication 5 May 1978

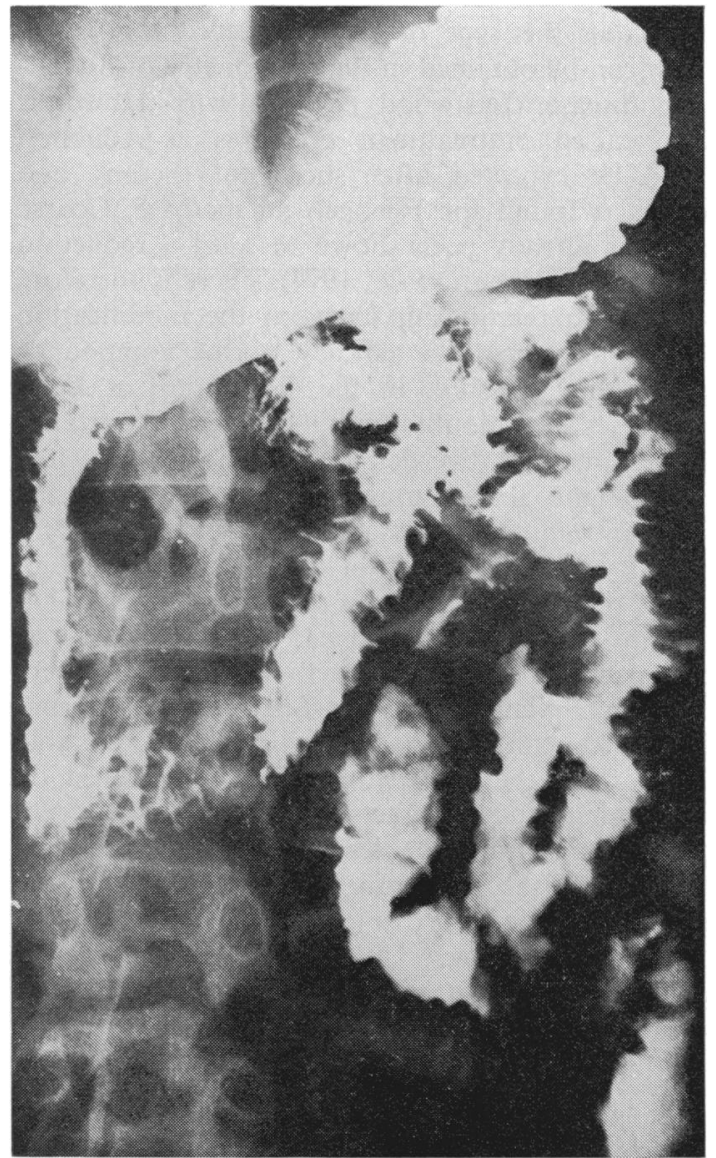

Fig. 1 Radiological features: thickened irregular folds in dilated loops along the whole small intestine. 
showed a severe malabsorption syndrome with intestinal hypersecretion and steatorrhoea (Table). Vitamin B12 absorption was not measured and ${ }^{51} \mathrm{Cr}$ albumin studies were not performed.

Table Main laboratory data

\begin{tabular}{ll}
\hline Serum proteins: & $48 \mathrm{~g} / \mathrm{l}$ \\
Albumin: & $23 \mathrm{~g} / \mathrm{l}$ \\
Alpha 1: & $2,4 \mathrm{~g} / \mathrm{l}$ \\
Alpha 2: & $6 \mathrm{~g} / 1$ \\
Beta: & $10 \mathrm{~g} / 1$ \\
Gamma: & $6,5 \mathrm{~g} / 1$ \\
Haemoglobin: & $133 \mathrm{~g} / 1$ \\
Serum iron: & $13,4 \mu \mathrm{mol} / 1$ \\
Serum calcium: & $2 \mathrm{mmol} / 1$ \\
Alkaline phosphatases: & $276 \mathrm{IU} / \mathrm{ml}$ \\
Faeces (24 h output) & \\
Stool weight: & $1.5-2 \mathrm{~kg}$ \\
Faecal fats: & $105 \mathrm{mmol} / 24 \mathrm{~h}$ \\
Search for pathogens, ova, and giardia : & $\mathrm{Negative}$ \\
Lactose load: & $\mathrm{No} \mathrm{glucose} \mathrm{rise} \mathrm{in} \mathrm{serum}$ \\
1 h xylose test: & $118 \mathrm{mg} / 1$ rise in serum \\
\hline
\end{tabular}

Marked clinical improvement occurred after treatment with tetracycline, cyclophosphamide, and corticosteroids. Diarrhoea subsided and lactose absorption markedly improved together with a decrease in the stool fat excretion (13 g per 24 hours). There was a moderate improvement of the histological lesions of the intestine and a moderate decrease in the level of the pathological serum protein. The patient left for Turkey after only three months of therapy.

Immunochemical analysis of sera of the patient and of her parents and sister was performed by electrophoresis and immunoelectrophoresis using polyvalent antisera and immune sera monospecific for each Ig heavy and light chain. Quantitative Ig determinations were done by the radial immunodiffusion technique (figures for IgG are not recorded because of lack of reliable standards).

Histological studies were performed with material obtained at several sites in the small intestine by peroral suction biopsies which were repeated during the course of the disease. Open biopsies of the intestine, liver, and mesenteric lymph nodes were also performed, as well as rectal biopsy and bone marrow aspirations. Histological material was stained by haematoxylin eosin, PAS, CHESA, and Gomori's silver staining methods. Frozen unfixed tissue sections were stained by methyl green pyronin and for acid phosphatase. Cytoplasmic immunofluorescence techniques were applied to cryostat sections of several intestinal and mesenteric lymph node specimens, using conjugates monospecific for the various Ig chains. These sections were extensively washed before ethanol fixation to remove extracellular protein. The preparation, characteristics, and specificity controls of the conjugated antisera have been reported in detail elsewhere (Seligmann et al., 1969).

\section{Results}

Electrophoresis of the patient's serum showed an abnormal broad band in the beta region accounting for roughly $10 \mathrm{~g} / \mathrm{l}$. Immunoelectrophoretic analysis with polyvalent antisera to normal human serum (Fig. 2A) showed an abnormal heterogeneous precipitation line which extended from the $\alpha 2$ to the $\beta 2$ region. This component reacted with anti-Ig and anti- $\gamma$ antisera and in these experiments the normal IgG line spurred over the line of the abnormal protein. It failed to react with several anti- $\kappa$ and anti- $\lambda$ antisera. As shown in Fig. 2B, the precipitation line of the abnormal protein completely crossed that of a $\kappa$ type Bence-Jones protein and did not inhibit its precipitation. Similar results were obtained with $\lambda$ type Bence-Jones proteins. Immunoselection with immunoelectrophoresis also confirmed the lack of light chains in the abnormal protein. Typing with subclass specific antisera showed that the abnormal protein exclusively contained determinants of the $\gamma 1$ subclass.

These results demonstrate that this protein was a $\gamma$ 1-HCD protein. By immunoelectrophoresis, normal IgG and IgA molecules appeared to be present in roughly normal levels, whereas IgM seemed to be decreased (Fig. 2A) and this was confirmed by radial immunodiffusion (IgA: $1.4 \mathrm{~g} / 1$ (140 mg \%); IgM: $0 \cdot 240 \mathrm{~g} / 1$ (24 mg \%). Results of immunochemical study of the sera of the patient's relatives were unremarkable.

Histological study of several intestinal biopsies taken in the duodenum and upper jejunum revealed a marked villous atrophy and an intense and regular infiltration of the lamina propria by lymphoplasmacytoid round cells (Fig. 3). This infiltration widely separated the crypts, which appeared hypoplastic. The villi were distorted and markedly shortened; some enterocytes were normal but most were cuboidal in appearance and devoid of a PAS positive brush border membrane. Numerous intraepithelial round cells were visible. The total height of the mucosa remained normal despite thickened folds. This pattern was found in all intestinal biopsies but varied in intensity. The clinical palpable abdominal tumours were found at laparotomy to arise from enlarged mesenteric lymph nodes of the ileocaecal region. Microscopically, the medullary cords of these lymph nodes were diffusely infiltrated by lymphoplasmacytoid round cells, with preservation of the sinuses and of sparse primary follicles. Within this diffuse infiltration, small aggregates of plasmacytoid cells surrounded by strands of delicate 


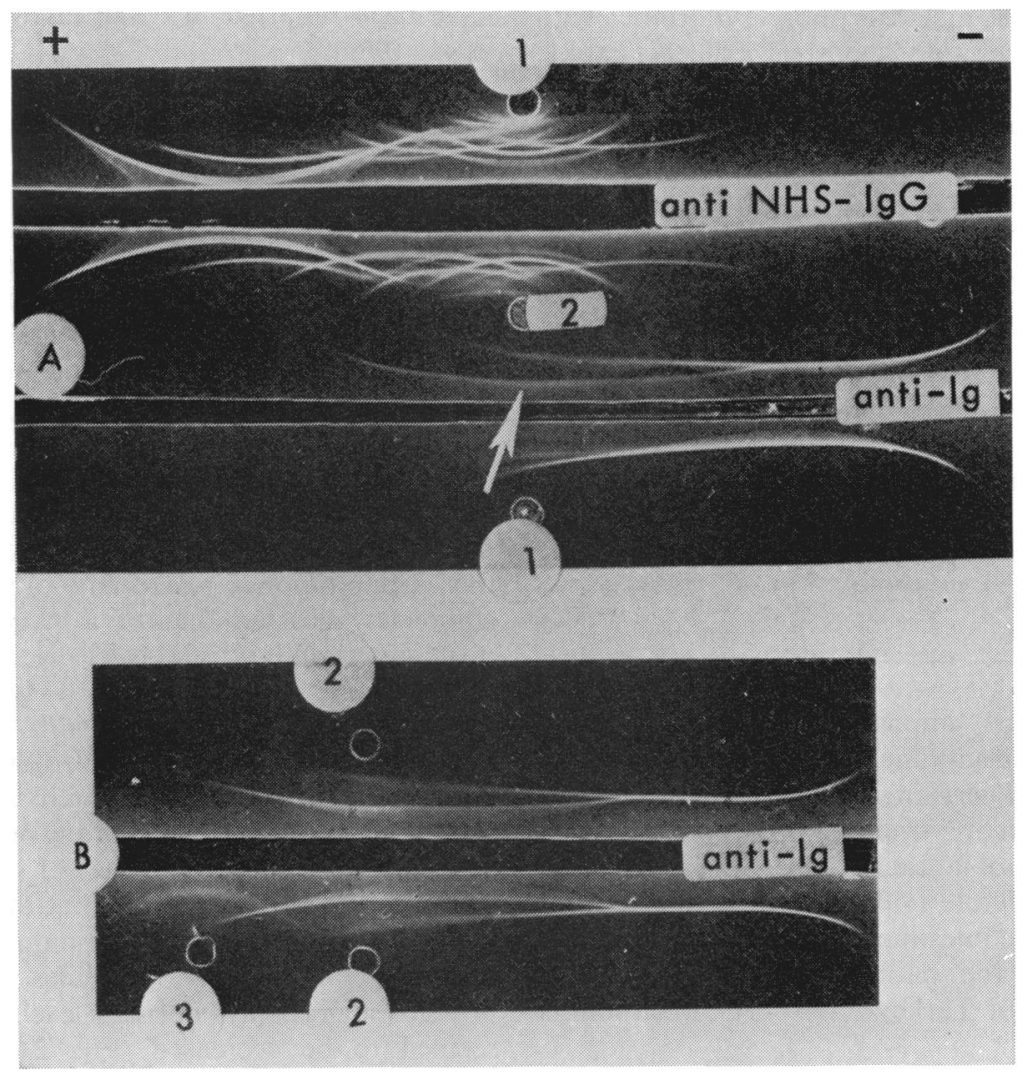

Fig. 2 Immunoelectrophoretic analysis of patient's serum. A: standard immunoelectrophoresis: anti NHS-IgG: polyvalent antiserum to normal human serum absorbed with normal IgG. anti-Ig: anti-immunoglobulin serum (mostly reacting with $\gamma, \kappa$ and $\lambda$ chain); 1: normal serum; 2: patient's serum. Note the broad precipitation line of the $\gamma-H C D$ protein (arrow). B: after electrophoresis of the patient's serum (2), a $\kappa$ type Bence-Jones protein was introduced in a new well (3) and the plate was developed with the anti-Ig serum. Note that the precipitation line of the Bence-Jones protein shows a reaction of complete nonidentity with that of the abnormal protein (it crosses the latter without decrease in intensity), whereas it continues into the normal $\operatorname{IgG}$ line. The normal IgG line does not spur over the line of the Bence-Jones protein because it is revealed only by the anti-light chain antibodies. Indeed the line of the $\gamma$ heavy chain, more external than that of normal $\operatorname{IgG}$, prevents the reaction of normal $\operatorname{IgG}$ with anti- $\gamma$ antibodies.

reticulin fibres could be demonstrated. Signs of overt neoplasia were not detectable in the intestinal mucosa nor in the mesenteric lymph nodes. Conventional histology of the rectal mucosa and the liver tissue was negative, as were the bone marrow smears.

Immunofluorescence studies of intestinal biopsies showed two clearly distinct types of Ig containing cells. In a strip right under the superficial epithelium and around the few glandular crypts, numerous typical plasma cells exhibited a normal distribution for heavy and light chains - that is, there were many cells staining for IgA, fewer for IgM and even fewer for IgG and more $\kappa$ than $\lambda$ containing cells. In this area, histochemical studies showed many pyroninophilic cells with a strong acid phosphatase activity. These presumably normal plasma cells became very sparse deeper in the mucosa where the cellular infiltrate was made of round cells with a high nucleocytoplasmic ratio which faintly stained for $\gamma$ and were negative for $\kappa$ and $\lambda$. These cells also differed from plasma cells by their faint or absent pyroninophilia and acid phosphatase activity. The same round cells containing $\gamma$ chains in the absence 


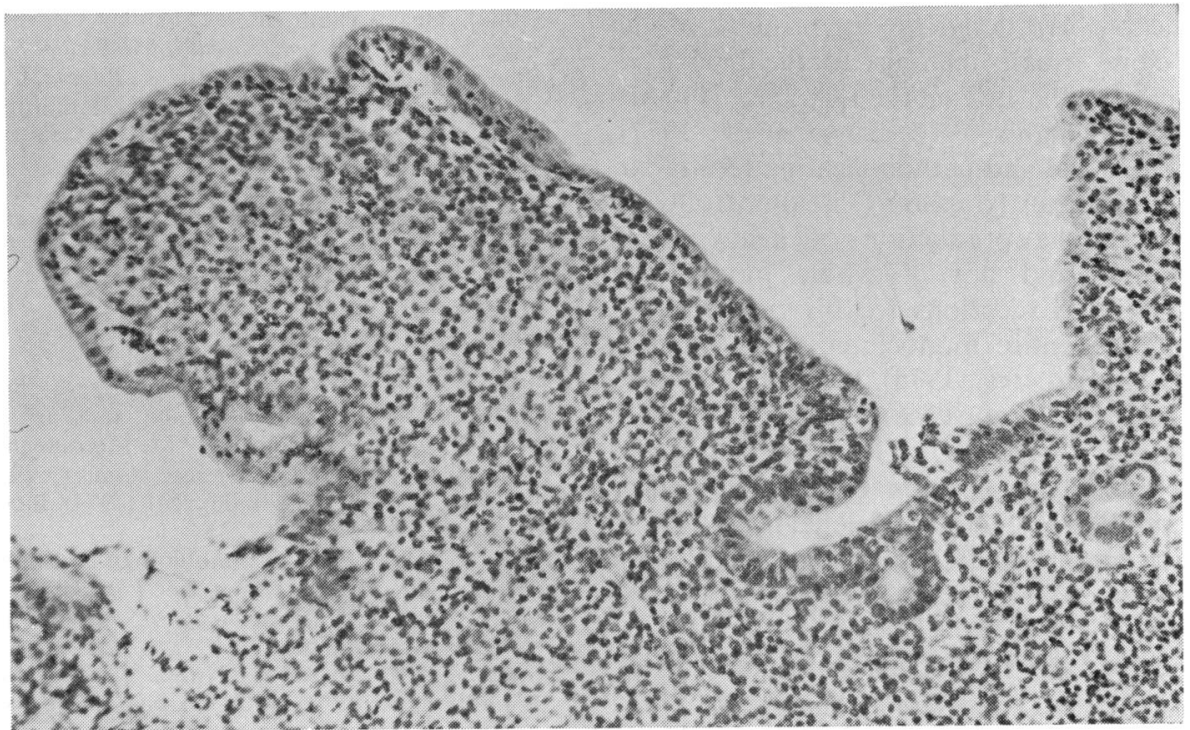

Fig. 3 Jejunal biopsy. Intensive diffuse infiltration by round cells with marked enlargement of the mucosal stroma. Note the dispersed and hypoplastic crypts, distorted and shortened villi, numerous intraepithelial round cells, and flattened enterocytes. $H$ and $E, \times 175$.

of detectable light chains predominated in the lymph nodes, which contained scattered typical plasma cells that mostly stained for IgG or IgA with light chains.

\section{Discussion}

The clinical and pathological features in our patient were those typically associated with the common form of $\alpha$ HCD (Rambaud and Seligmann, 1976). The patient's age and place of origin, the chronic diarrhoea with malabsorption, the diffuse involvement of the small intestine by lymphoplasmacytoid round cells without spreading outside the gastrointestinal tract strongly suggested $\alpha \mathrm{HCD}$. The pathological findings were analogous to those of the early possibly non-malignant stage of $\alpha$ CD (Rappaport et al., 1972; Galian et al., 1977). However, both the patient's serum and proliferating cells contained a $\gamma 1$ HCD protein. The faint immunofluorescence staining of these $\gamma$ containing cells was not surprising, as, in our experience, this faint positivity was the rule in classical $\alpha \mathrm{HCD}$ (Seligmann et al., 1969). The proliferating cells in the lamina propria and the mesenteric nodes consisted mainly of lymphoplasmacytoid round cells but not of mature plasma cells. This finding has been met with in some cases of $\alpha$ HCD (Tabbane et al., 1976). More uncommon was the finding in the subepithelial layer of intestinal biopsies of numerous plasma cells producing normal Ig molecules (mainly IgA), as, in $\alpha \mathrm{HCD}$, involved tissues are usually depleted in normal Ig producing cells. However, we have observed a similar pattern in a few cases of $\alpha$ HCD (Preud'homme, unpublished results).

On the whole, the findings in our patient differed from $\alpha$ HCD mainly by the class of the abnormal heavy chain. The proliferating cells presumably arise from IgG producing cells which are normally present in small amounts in the gut and which could have been triggered by local sustained antigenic stimulation (Watson, 1969; Seligmann, 1977). The extreme rarity of digestive $\gamma \mathrm{HCD}$ (as this is the first reported case) as compared to $\alpha$ HCD could well reflect only the normal distribution of intestinal $\mathrm{Ig}$ secreting cells (Crabbé and Heremans, 1966). We shall not discuss here the various problems of $\alpha$ $\mathrm{HCD}$, as they have been considered in detail elsewhere (Rambaud and Matuchansky, 1973; Rambaud and Seligmann, 1976; Seligmann, 1977). We wish only to point out that an immunoproliferative disorder, which usually affects immunocytes of one given Ig class, may occasionally involve cells synthesising another class (Salmon and Seligmann, 1974). This is similar to multiple myeloma where the proliferating clones usually produce IgG of IgA but where the malignant process may seldom affect an IgM producing clone. Also in B lymphocyte proliferations either with a maturation arrest (chronic lymphocytic leukemia, B type lymphomas) or with persistent differentiation into plasma cells (Waldenström's macroglobulinemia and analogous 
pleomorphic proliferations) the Ig product of the malignant clone usually belongs to the IgM class but sometimes to the IgG or the IgA class (Preud'homme and Seligmann, 1972; Tursz et al., 1977). The peculiar clinical and pathological pattern of socalled 'Mediterranean lymphoma' is almost always associated with the production of heavy chain disease proteins and not of whole monoclonal immunoglobulins. Exceptions to this rule are two patients with an entire monoclonal IgA (Chantar et al., 1974; Tangun et al., 1975). It should therefore be emphasised that in our case we found a $\gamma$ HCD protein and not a whole IgG. The meaning of the remarkable link between this clinicopathological condition and the production of deleted heavy chains is unknown and several hypotheses have been discussed elsewhere (Seligmann, 1977).

We are indebted to Professor K. Lennert, Kiel, FRG, and Professor H. Rappaport, Duarte, USA, for helpful advice in the interpretation of the histological findings, and to Professor G. Flandrin, Paris, France, for the histochemical study.

\section{References}

Chantar, C., Escartín, P., Plaza, A. G., Corugedo, A. F. Arenas, J. I., Sanz, E., Anaya, A., Bootello, A., and Segovia, J. M. (1974). Diffuse plasma cell infiltration of the small intestine with malabsorption associated to IgA monoclonal gammapathy. Cancer, 34, 1620-1630.

Crabbé, P. A., and Heremans, J. F. (1966). The distribution of immunoglobulin-containing cells along the human gastrointestinal tract. Gastroenterology, 51, 305-316.

Forte, F. A., Prelli, F., Yount, W. J., Jerry, L. M., Kochwa, S., Franklin, E. C., and Kunkel, H. G. (1970). Heavy chain disease of the $\mu(\gamma \mathrm{M})$ type. Report of the first case. Blood, 36, 137-144.

Franklin, E. C., Lowenstein, J., Bigelow, B., and Meltzer, M.
(1964). Heavy chain disease: A new disorder of serum $\gamma$-globulins. American Journal of Medicine, 37, 332-350.

Galian, A., Lecestre, M. J., Scotto, J., Bognel, C., Matuchansky, C., and Rambaud, J. C. (1977). Pathological study of alpha-chain disease, with special emphasis on evolution. Cancer, 39, 2081-2101.

Preud'homme, J. L., and Seligmann, M. (1972). Surface bound immunoglobulins as a cell marker in human lymphoproliferative diseases. Blood, 40, 777-794.

Rambaud, J. C., and Matuchansky, C. (1973). Alpha-chain disease. Pathogenesis and relation to Mediterranean lymphoma. Lancet, 1, 1430-1432.

Rambaud, J. C., and Seligmann, M. (1976). Alpha chain disease. Clinics in Gastroenterology, 5, 341-358.

Rappaport, H., Ramot, B., Hulu, N., and Park, J. K. (1972). The pathology of so-called Mediterranean abdominal lymphoma with malabsorption. Cancer, 29, 1502-1511.

Salmon, S. E., and Seligmann, M. (1974). B-cell neoplasia in man. Lancet, 2, 1230-1233.

Seligmann, M. (1977). Immunobiology and pathogenesis of alpha chain disease. In Ciba Foundation. Symposium 46 (New Series): Immunology of the Gut, pp. 263-281. Elsevier: Amsterdam.

Seligmann, M., Danon, F., Hurez, D., Mihaesco, E., and Preud'homme, J. L. (1968). Alpha chain disease: a new immunoglobulin abnormality. Science, 162, 1396-1397.

Seligmann, M., Mihaesco, E., Hurez, D., Mihaesco, C., Preud'homme, J. L., and Rambaud, J. C. (1969). Immunochemical studies in four cases of alpha-chain disease. Journal of Clinical Investigation, 48, 2374-2389.

Tabbane, S., Tabbane, F., Cammoun, M., and Mourali, N. (1976). Mediterranean lymphomas with alpha heavy chain monoclonal gammapathy. Cancer, 38, 1989-1996.

Tangun, Y., Saracbasi, Z., Inceman, S., Danon, F., and Seligmann, M. (1975). IgA myeloma globulin and BenceJones proteinuria in a diffuse plasmacytoma of small intestine (Letter). Annals of Internal Medicine, 83, 673.

Tursz, T., Brouet, J. C., Flandrin, G., Danon, F., Clauvel, J. P., and Seligmann, M. (1977). Clinical and pathologic features of Waldenström's macroglobulinemia in seven patients with serum monoclonal IgG or IgA. American Journal of Medicine, 63, 499-502.

Watson, D. W. (1969). Immune responses and the gut. Gastroenterology, 56, 944-965. 